Caries Res. 1969;3:300

\title{
Editorial Communication
}

The present Editor of Caries Research, Professor Yngve Ericsson, will resign following the termination of Vol. 3, 1969. The new Editor will be Professor Klaus König, Nijmegen. Professor Ericsson will remain on the Editorial Board, which otherwise will be unchanged.

Since more manuscripts have already been submitted than can be contained in Vol. 3 of the journal, from now onwards manuscripts should be sent to:

Prof. Klaus G. König

University of Nijmegen,

Preventieve Tandheelkunde

Heyendael,

Nijmegen (The Netherlands). 